\title{
O discurso eleitoral da Igreja Universal do Reino de Deus e a ascensão de Bolsonaro
}

\author{
The discourse of the Universal Church of the Kingdom of \\ God and Bolsonaro's Rise
}

\author{
Fabrício Roberto Costa Oliveira ${ }^{\circledR} \oplus$, Cáio César Nogueira Martins ${ }^{\mathrm{b}} \odot$
}

Resumo Este artigo apresenta uma análise da atuação política eleitoral realizada pelo jornal "Folha Universal”, pertencente à Igreja Universal do Reino de Deus (IURD), durante o Primeiro e o Segundo Turno das Eleições de 2018. Nosso foco de análise foram os editoriais e as reportagens de cunho político/eleitoral estampadas no semanário iurdiano. A pesquisa revela que o apoio a Jair Bolsonaro apenas se tornou contundente no final do Primeiro Turno, quando as pesquisas indicavam que ele tinha grandes possibilidades de ser eleito. Esse apoio não se dava com exposição do nome do candidato ou pedidos de votos explícitos, mas pelas pautas e elementos simbólicos das matérias publicadas, em que se repetiam jargões da campanha de Bolsonaro como a necessidade de acabar com a "velha política”, defender "valores da família tradicional" e a necessidade de se afastar do "comunismo". Tais concepções, no contexto eleitoral, demonstravam afinidades com a candidatura de Jair Bolsonaro. A presença quase exclusiva do candidato na Rede Record de televisão, emissora vinculada a Igreja Universal, ratificava a condição de apoiado pela instituição religiosa.

Palavras-chave Eleições 2018. Folha Universal. Igreja Universal do Reino de Deus. Bolsonaro.

Abstract This article presents an analysis of the electoral political performance carried out by the newspaper "Folha Universal", belonging to the Universal Church

a Doutor em Ciências Sociais em Desenvolvimento, Agricultura e Sociedade pela Universidade Federal Rural do Rio de Janeiro (UFRRJ). Mestre em Extensão Rural pela Universidade Federal de Viçosa (UFV). Graduado em História pela Universidade Federal de Ouro Preto (UFOP). Tem experiência na área de Sociologia, com ênfase em Sociologia da Religião e Sociologia dos Movimentos Sociais, atuando principalmente nos seguintes temas: religião e política, história das religiões, história oral e movimentos sociais. E-mail: fabriciooliveira@ufv.br.

b Mestrando do Programa de Pós Graduação em Ciência da Religião da Universidade Federal de Juiz de Fora (UFJF). Especialista em Direito Eleitoral pela Pontifícia Universidade Católica de Minas Gerais (PUC/Minas). Graduado em Ciências Sociais pela Universidade do Estado de Minas Gerais (UEMG). Graduado em Ciência Política pelo Centro Universitário Internacional (UNINTER). Graduado em Direito pela Universidade Presidente Antônio Carlos (UNIPAC). Tem experiência nas áreas do Direito, Ciência Política e Sociologia, dedicando-se a estudos sobre temas relacionados à participação da Mulher na Política e a relação entre Política e Religião. E-mail: caio_martins.007@hotmail.com 
of the Kingdom of God (IURD), during the First and Second Round of the Elections of 2018. Our focus of analysis was the editorials and the political/electoral reports printed in the "iurdianos" weekly. The survey reveals that support for Jair Bolsonaro only became blunt at the end of the First Round, when polls indicated that he had a high chance of being elected. This support was not given with an exhibition of the candidate's name or requests for explicit votes, but through the guidelines and symbolic elements of the published articles, in which Bolsonaro's campaign jargon was repeated, such as the need to end the "oldpolitics", defend "traditional family values"and the need to move away from "communism". Such conceptions, in the electoral context, demonstrated affinities with the candidacy of Jair Bolsonaro and his presence, appearing in a privileged way on Rede Record of television, also of the Universal Church, ratified the condition of being supported by the religious institution. Keywords Elections 2018. Folha Universal. Universal Church of the Kingdom of God. Bolsonaro.

\section{INTRODUÇÃo}

O objetivo deste artigo é apresentar uma análise das edições do Jornal Folha Universal, publicadas durante o período das eleições presidenciais de 2018. Este jornal pertence à Igreja Universal do Reino de Deus (IURD), popularmente conhecida como Universal, uma instituição religiosa evangélica fundada no Brasil em 1977, liderada pelo bispo Edir Macedo.

A Universal possui diversos templos no Brasil e no exterior, variada gama de redes de rádio e uma emissora de televisão, tal capilaridade lhe rende importante capital no campo religioso, mas também político. A IURD é a igreja brasileira que mais tem atraído fiéis desde a década de 1990, tal instituição tem agido em defesa da prosperidade financeira, praticando a cura divina e a libertação do poder do demônio (MARIANO, 2014).

Segundo dados do Censo de 2010, é a terceira maior igreja Pentecostal ${ }^{1} \mathrm{em}$ números de fiéis no Brasil, com um total de 1.783.243 seguidores, ficando atrás

1 Para Mariano (2014) a Reforma Protestante culminou no surgimento de diversas religiões evangélicas, ou melhor, de uma pluralidade de instituições que, muitas vezes, apresentam características teológicas, identitárias e organizacionais antagônicas, dentre elas o protestantismo norte-americano. Para o autor o Pentecostalismo brasileiro se subdivide em três tipos ideais, a saber: 1- Pentecostalismo clássico: cuja característica diferencial é a ênfase no "dom de línguas" (glossolalia), e são as denominações que inauguraram o Pentecostalismo; 2- Deuteropentecostalismo: caracterizado pelo evangelismo radiofônico centrado na cura divina, provocando a fragmentação denominacional e dinamizando a expansão do Pentecostalismo brasileiro; 3Neopentecostalismo: que se baseia na constante guerra contra o Diabo e seus representantes na terra (Teologia do Domínio), na difusão da crença de que todo cristão deve ser próspero, feliz e 
apenas da Assembleia de Deus ${ }^{2}$ e da Congregação Cristã do Brasil ${ }^{3}$. Dentre as instituições Neopentecostais brasileiras é tida como a maior em número de fiéis.

Uma das marcas características da IURD é a utilização de variados veículos de comunicação em massa para evangelizar, informar e se posicionar sobre diferentes assuntos perante a sociedade. Tais habilidades têm sido demonstradas pela IURD através do grande crescimento da Rede Record TV e da Rede Aleluia de emissoras de rádio, da inserção da igreja no mundo virtual através de seu site institucional, de perfis oficiais em redes sociais como o Facebook e o Twitter, da WebTu Universal e do canal de streaming Univer Vídeo, bem como a utilização de sua mídia impressa - o jornal Folha Universal. Para Mariano (2014), tanto nos templos quanto em suas mídias evangélicas, Jesus Cristo é propagandeado como a panaceia para todos os males terrenos.

Além da atuação religiosa e midiática, a Universal se destaca por sua atuação política. Oro (2003) já afirmava que ela pode ser considerada uma das igrejas mais atuantes na política institucional brasileira, crescentemente elegendo representantes para compor os quadros do Congresso Nacional no período pós-redemocratização.

Freston (1993) afirma que o engajamento evangélico foi intensificado a partir da Constituinte de 1988, justificado pelo receio do fim da liberdade religiosa e pela destruição da família. Lideranças evangélicas temiam o retorno da Igreja Católica como religião oficial, a aprovação do casamento entre pessoas do mesmo sexo e do divórcio, bem como a legalização das drogas e do aborto - pautas constantemente associadas ao comunismo e ao Diabo pelos evangélicos. A antiga expressão de que "evangélico não se envolve com política" passou a ser substituída pelo lema "irmão vota em irmão", principalmente entre iurdianos.

Desde a primeira eleição direta para a Presidência da República, a cúpula iurdiana vem se alinhando aos ocupantes do Palácio do Planalto, sejam estes governantes considerados de direita, esquerda ou centro.

Mariano (2014) aponta que em 1989 Edir Macedo apoiou entusiasticamente Fernando Collor de Mello (PRN/AL) e promoveu pesados ataques a campanha do petista Luiz Inácio Lula da Silva (PT/SP) após boatos de que, caso o petista fosse eleito, ordenaria o fechamento da Universal. Collor, por sua vez, prometera

vitorioso em seus empreendimentos terrenos (Teologia da Prosperidade), e por rejeitar usos e costumes de santidade pentecostais.

2 Segundo dados do Censo 2010 a instituição religiosa possui cerca de 12.314.410 fiéis no território nacional.

3 Segundo dados do Censo 2010 a instituição religiosa possui cerca de 2.289.634 fiéis no território nacional. 
a Macedo manter e ampliar as concessões de rádio e TV da Universal em troca de apoio. Entretanto, após escândalos de corrupção envolvendo o Presidente e seu ex-tesoureiro de campanha, Paulo César Farias, a bancada evangélica que dava sustentação ao governo Collor rompeu com o mesmo. Para Freston (1993), o Palácio do Planalto só notou que o impeachment seria aprovado pela Câmara dos Deputados quando soube que a bancada evangélica fecharia com a oposição. Collor sofreu impeachment por supostos crimes de corrupção no ano de 1992, sendo sucedido por seu vice Itamar Franco (PMDB/MG).

Ao receber de seu antecessor um país naufragado em uma profunda crise econômica (moeda desvalorizada e alto índice de inflação), Itamar Franco renovou seu gabinete ministerial e convidou para chefiar sua equipe econômica o sociólogo Fernando Henrique Cardoso, responsável por coordenar um novo plano econômico - o Plano Real. O sucesso do plano no controle da inflação fez de FHC forte candidato a suceder a Itamar ao Palácio do Planalto nas eleições de 1994.

Sobre as eleições de 1994, Mariano (2014) afirma que Macedo e seus aliados continuaram fazendo acirrada oposição aos candidatos petistas e, especialmente a Lula, que novamente se candidatara a Presidência da República. Naquela oportunidade as mídias iurdianas, em especial o jornal Folha Universal, mobilizaram conteúdos associando Lula ao comunismo, a Igreja Católica, ao Candomblé e, consequentemente ao Diabo. Não menos importante, a IURD acionou seu arsenal para acusar o Partido dos Trabalhadores (PT) de pretender legalizar o casamento homossexual e o aborto.

Naquele mesmo ano, pesquisas eleitorais realizadas as vésperas da eleição sinalizavam uma possível vitória de FHC (PSDB/SP) ainda em primeiro turno. Fato este que, atrelado ao interesse de proteger suas concessões midiáticas, foi crucial para Macedo manifestar apoio ao candidato, ainda que de forma discreta, conforme pontuado por Mariano (2014).

No ano de 1998, após a aprovação da Emenda Constitucional $n^{0} 16$ pelo Congresso Federal, FHC disputou a reeleição presidencial, tendo Lula novamente como seu principal oponente. Naquele ano, as ofensas a Lula e ao PT realizadas em períodos eleitorais pela Universal foram praticamente extintas, entretanto parlamentares ligados à igreja continuavam a dar sustentação ao governo.

Cruz (2009) aponta que a nova postura adotada pela IURD demonstrava certo descontentamento com o governo psdbista. Tal agastamento se fazia por dois motivos: a não interferência do alto escalão do governo nas operações realizadas 
pela Polícia Federal sobre as movimentações financeiras dos templos iurdianos ${ }^{4}$, bem como em razão do avanço de pautas ligadas ao aborto e a direitos à população LGBT, demandas estas relacionadas no Plano Nacional de Direitos Humanos (PNDH-I) aprovado pelo Governo em 1996 e cujas medidas seriam inseridas em um eventual segundo mandato presidencial.

O segundo governo de FHC foi marcado pelo aumento da taxa de desemprego, o endividamento do país com o Fundo Monetário Internacional, escândalos de corrupção envolvendo privatizações e denúncias sobre a suposta compra de parlamentares para a aprovação da Emenda Constitucional que permitiu a sua reeleição, fatos que dificultavam o Presidente eleger seu sucessor, o ex-ministro da Saúde José Serra (PSDB/SP).

Na conjuntura política da época, o apoio de Edir Macedo em 2002 a um candidato vinculado ao governo dificilmente seria proveitoso para a sua igreja. Assim, Nascimento (2019) rememora que no primeiro turno das eleições de 2002, a Universal apoiou Anthony Garotinho (PSB/RJ), que ficou em terceiro lugar. No segundo turno apoiou Lula (PT/SP), o antigo desafeto da instituição que antes era associado ao Diabo, e que a partir de então contava com o apoio da classe empresarial e era visto como um homem ético, oriundo do povo e comprometido com as causas sociais. Cruz (2009) complementa que o partido que antes era visto como representante do mal agora era valorizado por supostamente sustentar bandeiras contra a corrupção e contra as injustiças sociais, o que coadunava com os ideais cristãos defendidos pela igreja.

Lula sagrou-se vitorioso nas urnas, e seu governo foi marcado por grandes avanços no âmbito das políticas sociais. Entretanto, escândalos envolvendo a compra de apoio de parlamentares e de diversos partidos por parte de integrantes do governo resultaram em uma grave crise política nacional 5 e na exoneração de importantes ministros ligados ao Presidente.

Mesmo diante dos escândalos de corrupção, a reputação e popularidade de Lula permaneceram incólumes. Lula disputou novamente o cargo de Chefe máximo

4 Segundo Nascimento (2019), fiscais da Receita Federal do Brasil e auditores do Banco Central vinham se dedicando a análise das contas bancárias, movimentações financeiras e declaração de bens da IURD e da cúpula da igreja. Para o autor cerca de 4 mil contas foram vasculhadas e 1 milhão de cheques emitidos/recebidos foram rastreados.

5 Escândalo do Mensalão: esquema descoberto no ano de 2005 que consistia em pagamentos de propina mensalmente a diversos partidos políticos e parlamentares para darem sustentação ao governo do então presidente Lula. Escândalo dos Sanguessugas: também conhecido como máfia das ambulâncias, foi um esquema de corrupção envolvendo fraudes em licitações e superfaturamentos na aquisição de ambulâncias com dinheiro público. $\mathrm{O}$ esquema liderado por alguns deputados federais veio a público no ano de 2006, dentre os envolvidos estava o ex-deputado Carlos Alberto Rodrigues Pinto, bispo e coordenador político da Igreja Universal. 
do Executivo Federal no ano de 2006. Sob a promessa de continuidade de avanços na seara social, Lula avançou para o segundo turno e derrotou o candidato Geraldo Alckmin (PSDB/SP), garantindo assim a sua reeleição.

Importante peça para o segundo mandato de Lula foi Dilma Rousseff (PT/ RS). Ao passar pelos ministérios das Minas e Energia e da Casa Civil, tornou-se a candidata apadrinhada pelo Presidente para sucedê-lo nas eleições de 2010. Com a promessa de continuação dos governos de Lula, Dilma era propagandeada pela mídia iurdiana como a representante da moral evangélica.

Assim como nos governos de seu antecessor, o governo Dilma foi marcado por avanços sociais e escândalos de corrupção, desta vez envolvendo a Petrobrás, empreiteiras brasileiras e diversos parlamentares. No ano de 2013 o governo foi surpreendido com inúmeros protestos contra a classe política e em defesa do Judiciário. Mesmo com sua imagem desgastada e a diminuição de sua popularidade, Dilma tentou a reeleição em 2014.

Martins (2020) considera que diante do desgaste da então Presidente e da indefinição do cenário eleitoral, a IURD optou pela neutralidade política durante o período eleitoral daquele ano. Dilma Rousseff derrotou Aécio Neves (PSDB/MG) por uma diferença próxima a três milhões de votos. O seu segundo mandato foi marcado pelo agravamento da crise política e um colapso econômico. Ainda nos primeiros meses de seu segundo mandato, a popularidade da Presidente diminuiu vertiginosamente, e sob a alegação de suposta prática de crime de responsabilidade, se iniciou um processo de impeachment contra a mesma.

Com o impeachment de Dilma, seu vice Michel Temer (PMDB/SP) assumiu o cargo de Presidente. A IURD deu grande sustentação ao novo governo, prova disso foi o convite feito a Marcos Pereira, político ligado a cúpula iurdiana, para ocupar o ministério da Indústria, Comércio Exterior e Serviços, cargo que exerceu entre os anos de 2016 e 2018.

Às vésperas do Primeiro Turno da eleição presidencial de 2018, Edir Macedo declarou apoio ao presidenciável Jair Bolsonaro (PSL/RJ - atualmente sem partido) ${ }^{6}$. Casado com uma evangélica batista (Michele Bolsonaro), o capitão do Exército e deputado federal abraçou as pautas conservadoras dos evangélicos e, com um discurso contra a corrupção da "velha política”, e em defesa da Pátria e da família cristã, consolidou-se como principal opção ao antipetismo.

6 Reportagem veiculada no Jornal Estadão em 30/o9/2018, às vésperas da realização do Primeiro Turno das Eleições Presidenciais 2018. Fonte: https://politica.estadao.com.br/noticias/ eleicoes,edir-macedo-declara-apoio-a-bolsonaro,70002526353. Acessado em: 04 nov. 2018. 
Durante as eleições de 2018 houve uma aproximação efetiva entre Jair Bolsonaro e a principal liderança da IURD, com diversas entrevistas exclusivas concedidas pelo então candidato à Rede Record. Nascimento (2019) esclarece que tal estratégia de se associar a pretensos ocupantes do Palácio do Planalto busca salvaguardar interesses como a aprovação de legislações que contemplem pautas defendidas pelos iurdianos, isenções tributárias em prol dos empreendimentos da igreja, a ascensão de pessoas ligadas à IURD a cargos do alto escalão dos governos e a barganha de apoio de congressistas evangélicos ao governo em troca da garantia de novas concessões midiáticas e da manutenção das já existentes.

Frente a todo o exposto, optamos por analisar como o jornal impresso iurdiano mobilizou conteúdos se referindo diretamente à política partidária durante o "tempo da política" no ano de 2018 e a forma como isso aconteceu, com foco específico no Editorial e nas reportagens diretamente vinculadas às eleições7.

Além dessa introdução, nosso texto está dividido em outras três partes. Na primeira parte, nos incumbiremos de delinear a metodologia de nossa pesquisa. $\mathrm{Na}$ segunda parte, nos debruçaremos na análise da mobilização de conteúdo político/ eleitoral no jornal Folha Universal durante o Primeiro Turno das Eleições de 2018, e na terceira parte, faremos uma análise dos conteúdos relacionados ao segundo Turno das Eleições de 2018. Por fim, apresentaremos nossas Considerações Finais.

\section{METODOLOGIA DE PESQUISA}

O segmento evangélico compõe uma parcela significativa da sociedade brasileira e não podemos ignorar sua atuação para além dos espaços sagrados. Para Nascimento (2017) devemos reconhecer que a religião exerce influência sobre seus membros - não apenas por causa da doutrina teológica, mas também desenvolve um senso de comunidade, identidade e pertencimento.

Desta forma, estudos clássicos como os realizados por Pierre Bourdieu (2005, 2011) demonstram que diversos microcosmos, como religião e política, podem ser relativamente autônomos, mas também podem estar diretamente relacionados entre si. Ao analisar a constituição do campo religioso, Bourdieu (2005) defende que a religião tem um caráter político, porque ela dá sentido àquilo que existe ou venha a existir. Sua função lógica de ordenação do mundo acaba por recobrir divisões sociais de grupos ou classes concorrentes ou antagônicas, reafirmando o caráter legitimador da produção simbólica. Noutras palavras, os discursos empu-

7 Durante o Período Eleitoral o jornal Folha Universal publicou 11 edições de seu semanário. Cada edição contou com tiragem superior a 1.850.000 unidades. 
nhados pelos clérigos têm o condão de assumir uma função ideológica capaz de interferir na construção e na percepção do mundo social e, desta forma, os líderes religiosos se valem de sua autoridade e de seu capital religioso para naturalizar e rotinizar suas concepções mundanas entre os leigos.

Neste ínterim, torna-se imperioso destacar que um dos canais utilizados pela IURD para se posicionar é através do semanário "Folha Universal", mídia impressa consolidada há quase 30 anos entre os fiéis da instituição religiosa, o que torna o jornal um importante material empírico de pesquisa, principalmente para a análise dos discursos empregados para fins profanos, especificamente no âmbito da política.

Conrado (2001) acrescenta que a Folha Universal marca o período eleitoral no cotidiano da IURD. Segundo o autor, é através do jornal que os conflitos são explicitados e um arsenal de bens simbólicos é produzido e reproduzido na busca de representação política e do voto corporativo.

Para Rocha (2006) a Folha Universal tem como principal característica sua linha editorial tendenciosa, destacando que em anos eleitorais, o jornal era costumaz na promoção de ataques aos opositores dos candidatos da IURD, e que os bispos exerciam grande pressão sobre o conteúdo do jornal.

Essas preocupações com notícias mais voltadas para o campo político têm relação direta com a aproximação de períodos eleitorais. Os estudos de Palmeira (1997) revelam que para muitas pessoas a política não é uma atividade permanente, se fazendo presente no cotidiano somente com a proximidade das eleições. Assim, o "tempo da política" é compreendido como um recorte social do tempo em que os candidatos vão para a arena política competir por adeptos, e que as instituições e eleitores optam por manifestar simpatia a um dado candidato para se situarem de um lado da sociedade, ou para reforçar o pertencimento a determinado grupo.

Diante do exposto até o momento buscamos analisar como o jornal impresso mobilizou seus conteúdos se referindo diretamente à política partidária durante o "tempo da política" e a forma como isso aconteceu, com foco no editorial e nas reportagens diretamente vinculadas às eleições.

Durante o Primeiro Turno foram publicadas 07 edições do semanário iurdiano ${ }^{8}$. Já no decorrer do Segundo Turno foram publicadas 04 edições $^{9}$. Por tratar-se de um jornal extenso, aproximadamente 32 páginas, e que a cada edição aborda diversos temas, nosso maior desafio foi filtrar os textos de cunho político/eleitoral. Através

8 Edições publicadas entre 16 de agosto e 07 de outubro de 2018.

9 Edições publicadas entre o8 de outubro e 28 de outubro de 2018. 
da leitura de todo o material empírico coletado e discussão sobre a relação do que estava escrito com a política partidária, identificamos 57 textos relevantes para nosso estudo entre editoriais e demais matérias.

A seguir faremos uma análise mais acurada acerca dos principais temas de cunho político/eleitoral publicados pelo semanário iurdiano, no ano de $2018^{10}$.

\section{A FOLHA UNIVERSAL E 0 PRIMEIRO TURNO DAS ELEIÇÕES DE 2018}

Ao analisarmos as 07 edições semanais publicadas durante o período do Primeiro Turno (Ed. 1.375, 1.376, 1.377, 1.378, 1.379, 1.380 e 1.381) identificamos a existência de 07 editoriais e 37 notícias de cunho político/eleitoral.

Fato importante para compreender a dinâmica eleitoral do período é a indefinição da candidatura petista ao Planalto. Lula figurava em vantagem como preferência nacional entre os entrevistados pelos institutos de pesquisa, entretanto o candidato encontrava óbices jurídicos para o deferimento de seu registro de candidatura. A condenação criminal por crime de corrupção passiva e lavagem de dinheiro proferida pelo juiz titular da $13^{\text {a }}$ Vara Federal de Curitiba, e confirmada pela $8^{\text {a }}$ Turma do Tribunal Regional Federal da $4^{\text {a }}$ Região, retirou o candidato do páreo. Já iniciada a campanha eleitoral, o PT optou por substituir a candidatura de Lula pela de Fernando Haddad (PT/SP) ${ }^{11}$. Haddad não gozava da mesma simpatia que Lula, fato este que possibilitou a Jair Bolsonaro ocupar o primeiro lugar nas pesquisas eleitorais.

Naquele contexto, as redes sociais eram bombardeadas por conteúdos políticos das mais diversas linhas ideológicas. Notícias falsas e montagens gráficas eram frequentemente produzidas e disseminadas com intuito de modificar a opinião dos eleitores acerca dos candidatos e alterar a preferência do eleitorado.

No editorial intitulado "Facebook e a possível má influência nas eleições"(Ed. 1.375, p.o3) o jornal reconhecia que, assim como em outros países, o fenômeno das Fake-News se fazia presente, destacando que as redes sociais vinham recebendo críticas devido à fragilidade na segurança dos dados de seus usuários. Para ilustrar a fragilidade desses dados mencionou o escândalo envolvendo a empresa de consultoria britânica Cambridge Analytica que combinava captação e análise de dados do Facebook com comunicação estratégica, direcionando aos perfis dos

10 Embora tenhamos estudado todas as 51 edições do jornal Folha Universal publicadas no ano de 2018, neste trabalho abordaremos somente as edições publicadas durante o Primeiro e o Segundo Turno das eleições.

11 Fernando Haddad era vice na chapa de Luiz Inácio Lula da Silva. Com o indeferimento do registro da chapa, o Partido dos Trabalhadores optou por formar a chapa Fernando Haddad (PT) e Manuela D’Ávila (PCdoB). 
usuários conteúdos de forma a intervir na opinião do eleitorado, interferindo diretamente nas eleições norte americanas de 2016. O jornal pontuava positivamente o fato de o Facebook ter banido no Brasil 196 páginas e 87 perfis que buscavam disseminar Fake-News de caráter eleitoral. Ao se colocar como jornal que condena Fake-News, a Folha Universal procurou se legitimar junto aos leitores como fonte isenta e defensora da verdade, condição simbólica importante para influenciar nas decisões dos fiéis.

Sobre as Fake-News, Recuero e Gruzd (2019) consideram que três elementos são essenciais para a sua definição: o uso da narrativa jornalística e dos componentes noticiosos; a falsidade total ou parcial da narrativa e; a intencionalidade de enganar ou criar falsas percepções através da propagação dessas informações na mídia social. Neste sentido, Almeida (2019) acrescenta que além do Facebook as plataformas do Twitter e WhatsApp tiveram papel decisivo na deslegitimação dos candidatos que disputaram as eleições em 2018, aumentando-lhes a rejeição em razão da rápida circulação de mensagens falseadas.

O jornal era taxativo na premissa de que não era possível abandonar a política e que se fazia necessário participar de audiências públicas, ler portais, estar sempre informado e não compartilhar conteúdos duvidosos. Sob a ótica dos preceitos teológicos da IURD, estar bem informado resulta na escolha de políticos de bem, o que pode ser associado com a Teologia do Domínio e sua insistente empreitada contra o mal.

A consequência desse discurso é que para os fiéis iurdianos votar não constitui apenas um exercício de cidadania. Ele também é concebido como um ato que preenche um sentido quase-religioso. Trata-se de um gesto de exorcismo do demônio que se encontra na política e de sua libertação para que ela seja ocupada por "pessoas tementes ao Senhor Jesus" (ORO, 2003, p. 58).

Embora as mídias religiosas tenham o condão de serem informativas, não se descuidam do objetivo de evangelizar e defender os interesses da igreja e de suas lideranças. São elas que propagam mensagens e apontam o que está certo ou errado, o que pode ser realizado ou não pelos fiéis. Assim o tema "Ideologia de Gênero" permeou os debates políticos e foi explorado pelo semanário durante o Primeiro Turno. Esta foi uma das temáticas mais fundamentais daquela eleição, houve uma articulação consistente entre o conservadorismo religioso e a proposta eleitoral de Jair Bolsonaro de uma política liberal na economia e conservadora 
nos costumes. Tratou-se de uma eleição que ocorrera em grande medida na esfera da moral (MoufFe, 2015).

O debate sobre gênero estava presente na política brasileira há algum tempo. Reis e Eggert (2017) relembram que durante os anos 2000, diversos órgãos internacionais como a Organização das Nações Unidas (ONU) e a Organização dos Estados Americanos (OEA) vinham firmando o entendimento de que são direitos humanos a equidade de tratamento entre sujeitos, principalmente no que tange a orientação sexual e a identidade de gênero, recomendando que os países adotem medidas a fim de combater e punir atos de violência e discriminação contra mulheres, gays, lésbicas, bissexuais, travestis e transexuais.

Em 2013, ao se discutir o novo Plano Nacional de Educação, a temática passou a ocupar os holofotes do Congresso Nacional e da sociedade brasileira. Enquanto políticos situados mais à esquerda do espectro político defendiam o amplo debate sobre a temática nas escolas e na sociedade, a fim de combater a intolerância à diversidade de gênero e sexual, parlamentares situados mais à direita e setores mais conservadores da sociedade, como os religiosos, combatiam a prática sob o argumento de que o projeto destruiria os valores familiares.

Nascimento (2019) pontua que Haddad ${ }^{12}$ recebia constantes críticas dos evangélicos por, supostamente, ser o responsável pelo lançamento de um "Kit-gay" nas escolas, termo pejorativo utilizado para se referir ao material didático do programa Escola sem Homofobia. Bolsonaro, por sua vez, era conhecido como ferrenho opositor aos direitos das minorias, se destacando por constantemente proferir frases de caráter misógino, machista e preconceituoso na mídia. No contexto da eleição de 2018 procurava se colocar como defensor dos valores da família cristã e aproximar a imagem de Haddad a do político do "Kit-gay", algo que convenceu boa parte do eleitorado.

Bolsonaro acusava a mídia e os partidos de esquerda de disseminar a diversidade sexual e de gênero, fato este encampado pelos evangélicos conservadores e pela linha editorial do jornal Folha Universal. Esta afinidade contribui para a consolidação da relação de cooperação do Jornal com a campanha de Jair Bolsonaro. As escolhas dos temas das matérias estavam diretamente atreladas aos debates do "calor do momento". Tratava-se de uma bricolagem de interesses: religiosos, políticos e comerciais, entre outros.

É possível perceber, por exemplo, como o tema político emerge como destaque numa profunda crítica à Rede Globo de Televisão, concorrente da Rede Record que

12 Fernando Haddad comandou o Ministério da Educação durante os anos de 2005 a 2012. 
também pertence à Universal. Na reportagem intitulada "Novela para adolescente promove ideologia de gênero" (Ed. 1.376, p. o8), o jornal iurdiano problematizou uma cena da novela Malhação, exibida pela Rede Globo, cujo público-alvo são os adolescentes. Afirmava que o assunto quando empurrado "goela abaixo" ocasionava confusão sexual ou estímulo precoce a sexualidade. Em outra oportunidade, o jornal publicou editorial intitulado "A ditadura da ideologia de gênero"(Ed.1.379p. o3), posicionando-se contra a abordagem do tema nas escolas e criticando a mídia que tenta naturalizar o assunto através das novelas. Na edição 1.380, a matéria "Roupas para meninos e meninas podem estar com os dias contados" foi dedicada a construir uma concepção segundo a qual as moralidades e a educação estariam em risco e que seria fundamental votar em um candidato que fosse defensor da família brasileira e da educação tradicional.

Bourdieu (2014) considera que a escola significa para o campo cultural o mesmo que a igreja significa para o campo religioso, sendo capaz de orientar o comportamento das pessoas. Assim, os evangélicos partem da premissa de que ao se difundir a temática da "Ideologia de Gênero" no âmbito escolar se relativizaria entre crianças e adolescentes preceitos morais evangélicos como o casamento entre homem e mulher e o ato sexual com finalidade exclusiva de procriação da espécie humana. Nesta ótica teríamos como resultado a destruição do modelo familiar tradicional cristão e, consequentemente, uma ofensa a Deus.

Imperioso destacar que Bolsonaro já havia participado de uma sabatina no jornal de maior audiência da Rede Globo de Televisão e reiterado que livros estimulavam a homossexualidade e teriam sido distribuídos pelos governos petistas as escolas de ensino primário, o que ficou constatado posteriormente como Fake-News ${ }^{13}$. Não obstante, no campo político, o tema tinha enorme capacidade de mobilizar grandes contingentes que estavam muito mais preocupados em defender um modelo de família tradicional e patriarcal do que em um processo educativo capaz de promover diálogo e relações mais profícuas entre os diferentes gêneros.

Na reportagem intitulada "Por que o7 de outubro será o Dia das Crianças?" (Ed. 1.381, p. 16) o jornal mencionava o Projeto de Lei 5.002/2013 que pretendia criar a Lei de Identidade de Gênero. Segundo a reportagem o projeto foi proposto pelos deputados Jean Wyllys (PSOL/RJ) e Erika Kokay (PT/DF), estabelecendo a possibilidade de realização de cirurgia de mudança de sexo por crianças sem o consentimento dos pais. Uma informação falsa, mas que tinha potencial de

13 Entrevista concedida ao Jornal Nacional em 28/o8/2018. Disponível em: https://globoplay.globo. com/v/6980200/ . Acessado em 24 jun 2021. 
mobilizar paixões religiosas e políticas e causar sensação de pânico moral. Interessante perceber como o mesmo jornal que aprovava a punição às Fake-News estava se valendo das mesmas para mobilizar politicamente seus leitores. Nessa problemática difícil das eleições de 2018 houve uma grande batalha simbólica em torno da definição da "verdade".

Para Rodrigues (2020), ao ocuparem espaços públicos e políticos, as lideranças religiosas baseiam seus discursos em certa tradição bíblica, cuja moral separa o certo e o errado, o bem e o mal, o papel do homem e da mulher, e a todos que se mostrarem contrários a esse sistema moralizante, cabe o combate e a deslegitimação. Desta forma, ao atribuir a parlamentares do PT e do PSOL a autoria e apoio a projetos relacionados à ideologia de gênero, o jornal mobilizava seu arsenal em prol de promover o descrédito dos presidenciáveis destes partidos, principalmente a desconstrução da imagem de Fernando Haddad (PT/SP).

O jornal insistia que o voto seria um importante instrumento para frear aqueles que buscam destruir valores cristãos importantes como a família e a liberdade de professarem a fé. Neste sentido, Rodrigues (2020) completa que os valores religiosos perpassam por certas normas que determinam como o evangélico deve agir socialmente, na perspectiva de agradar a Deus.

No editorial intitulado "Cuidado, não vote contra a fé" (Ed. 1.381) o jornal destacou a polêmica sobre um projeto de Lei na China que previa a proibição de diversos conteúdos de várias crenças na internet. Afirmava que na Bolívia algo parecido também ocorreu quando o governo federal de lá tentou criminalizar a evangelização. Dessa forma, o jornal reforçava que era preciso ter cuidado na escolha dos políticos, pois havia vários candidatos com diferentes crenças, opiniões e linhas de pensamento, entretanto seria prudente a escolha de líderes que defendiam publicamente os princípios de Deus, como a família e a liberdade de poder expressar a fé, reforçando mais uma vez a importância do voto consciente e responsável. "Deus, família e liberdade" eram termos muito caros à campanha de Jair Bolsonaro. Naquele contexto não era difícil perceber que na perspectiva do jornal, votar no PT era apoiar o "Kit-gay", e isso implicava votar "contra a fé". Os símbolos e narrativas mobilizados não requeriam que se utilizasse os nomes de candidatos.

O que se percebeu foi a utilização de um discurso de pânico. Segundo Mariano e Gerardi (2020, p. 330), pastores e parlamentares evangélicos, sacralizaram "a direita política, demonizaram o PT e o candidato petista, tratando-os como anticristãos e atestando que a eleição de um "esquerdopata" representava riscos à liberdade religiosa, de bolivarianismo, erotização de crianças em escolas e destruição da família”. 
Muito embora o antigo PRB (atual Republicanos - legenda com fortes ligações com a IURD $\left.{ }^{14}\right)$, tenha integrado a coligação do presidenciável católico Geraldo Alckmin (PSDB/SP), insta destacar que em momento algum o jornal publicizou o apoio do partido ou declarou apoio da igreja ao candidato. Tal fato pode ser justificado pela estagnação do mesmo nas pesquisas eleitorais e incertezas quanto ao seu avanço ao Segundo Turno. Nesse sentido, pode se dizer que editores do jornal são estratégicos no posicionamento político e que mesmo o PRB sendo um partido que agrega os agentes da IURD, este procura não revelar abertamente essa relação, procurando se mostrar como um jornal que alerta para a necessidade de um voto consciente e não diretamente a um grupo político.

O Bispo Edir Macedo "declarou apoio a Bolsonaro no Facebook em 29 de setembro. No embalo, a Igreja Universal reproduziu vídeos contra o "Kit-gay", a Record $T V$ e o $R 7$ franquearam espaço ao candidato do PSL, o PRB desmobilizou a campanha pró Geraldo Alckmin (PSDB) e engajou-se na do capitão" (MARIANo; GERARDI, 2020, p. 340). Não obstante, as edições estudadas não fizeram qualquer menção direta ao nome de Jair Bolsonaro ou outro candidato à presidência, contudo é possível identificar afinidades entre os posicionamentos, tanto do semanário quanto do presidenciável Jair Bolsonaro, principalmente a defesa de pautas como a preservação da instituição familiar nos moldes heteronormativos e a consequente oposição a "Ideologia de Gênero". Não se pode afirmar que os conteúdos mobilizados pelo jornal da IURD neste período foram decisivos para o avanço do candidato ao Segundo Turno, entretanto não se pode minimizar sua importância simbólica e mobilizadora de agentes religiosos e políticos.

\section{A FOLHA UNIVERSAL E 0 SEGUNDO TURNO DAS ELEIÇÕES DE 2018}

Realizadas as eleições em Primeiro Turno, Jair Bolsonaro e Fernando Haddad foram os dois candidatos mais bem votados, recebendo o primeiro 46,03\% e o segundo 29,28\% dos votos válidos, caminhando assim para a disputa em Segundo Turno ${ }^{15}$. Naquele contexto as pesquisas de intenção de votos evidenciavam uma

14 Gutierrez (2016) destaca que muito embora o antigo PRB, atual Republicanos, se preocupe em relegar sua proximidade com a IURD e mostrar-se um partido laico, a escolha de Marcos Pereira como presidente da legenda, bem como a composição significativa dos cargos de direção do partido por pessoas ligadas a igreja evidenciam as relações entre ambas as instituições. Para Martins (2020), dentre os 27 presidentes das Comissões Provisórias Estaduais em exercício no ano de 2020, ao menos 12 possuem vínculos com a IURD, o que corresponde a 44,44\%. No que tange a Executiva Nacional do partido, formada por 16 integrantes, ao menos o9 são membros da IURD, o que corresponde a 56,25\%. Quase todos são bispos ou pastores da igreja de Edir Macedo.

15 Dados do Tribunal Superior Eleitoral. Disponível em: http://www.tse.jus.br/eleicoes/eleicoes-2018/votacao-e-resultados/resultados-eleicoes-2018. Acessado em o6 mai. 2020. 
grande rejeição ao candidato do PT e as chances de Bolsonaro ser eleito eram elevadas.

Durante o período do Segundo Turno foram publicadas 04 edições semanais (Ed. 1.382, 1.383, 1.384 e 1.385). Em todos os 04 editoriais o tema era as eleições e nas edições havia 09 notícias de cunho político/eleitoral. Verificamos a persistência do semanário em informar os fiéis acerca da importância do voto, instrumento capaz de mudar politicamente do país. A ideia de mudança reforçava a candidatura de Jair Bolsonaro que se colocava como opositor à "velha política". Temáticas como o ódio nas redes sociais, a moral religiosa e a defesa do direito de manifestação política de pastores e bispos marcaram a tônica das publicações naquele período.

No editorial intitulado "A agressão nos assuntos políticos movimenta as redes sociais" (Ed. 1.382, p. 03), o jornal destacou que durante o Primeiro Turno muitos eleitores foram levados pelas emoções, momento em que o antagonismo e a polarização ganharam espaço, assim como o ódio substituiu as propostas. Familiares e amigos estavam brigando por conta de comentários políticos postados na internet.

O jornal destacava que pesquisas desenvolvidas pela UFMG e pelo instituto Datafolha sinalizavam que os cidadãos estavam mais interessados em discutir política, entretanto ressaltava que o aumento do interesse pela política não garantia a qualidade do debate e nem a solução para os problemas do país, sendo necessário que a população permanecesse unida e se mantivesse informada, além de cobrar e fiscalizar o trabalho dos representantes eleitos.

Havia uma forte polarização entre os apoiadores da esquerda e da direita. Enquanto uma boa parte da classe artística declarava apoio a Fernando Haddad, diversas lideranças do segmento evangélico já haviam expressado o voto em Jair Bolsonaro, fato fortemente publicizado e criticado pela mídia. Assim, a defesa do direito de manifestação política de pastores e bispos também ganhou destaque no semanário iurdiano. No editorial intitulado "Dois pesos e duas medidas"(Ed. 1.383, p. 03), o jornal demonstrava indignação com o fato de a cantora Pabllo Vittar ter se manifestado contra Bolsonaro em um programa de TV, enquanto os pastores da instituição não podiam se expressar politicamente em seus templos sem sofrer sanções da Justiça e perseguições da mídia. Estava subentendido que moralmente o pastor teria muito mais legitimidade para se expressar sobre o futuro do país do que uma drag queen que seria moralmente condenável e representava uma espécie de pecado a ser combatido pela instituição.

Discursivamente o jornal evidenciava a existência de duas visões de mundo antagônicas, o "nós", representado pelos evangélicos que moralmente vivem e professam os valores iurdianos, e o "eles", segmento que se opõe as pautas defen- 
didas pela igreja. Para Mouffe (2015) a construção da identidade acerca do nós/eles, embora perpasse pela relação entre dois grupos, não necessariamente se reveste de um caráter antagonístico, exceto quando se acredita que um destes grupos constitui ameaça ao outro. Neste caso específico se tratava de "ameaça": de um lado, pastores conservadores viam a militância pelos direitos sexuais uma afronta à família tradicional brasileira e de outro, grupos LGBTQIA+ viam na eleição de grupos tão conservadores uma guinada de violência e retirada de direitos.

O assunto se repetiu no editorial intitulado "O espírito da lei não é a lei contra o espírito" (Ed. 1385, p. 03), quando o jornal criticou aqueles que defendiam que a fé não poderia ser motivo para os eleitores escolherem seus candidatos. $O$ texto esclarecia que embora a legislação eleitoral proíba campanha em bens públicos e de uso do povo, como as igrejas, os pastores e quaisquer outros religiosos não estão impedidos de se posicionarem politicamente em grupos de WhatsApp, em conversas ou de subirem em palanques durante comícios. Defendia que os líderes espirituais deveriam alertar e debater com sua comunidade questões políticas e que cada voto seria poderoso para definir os rumos do país, destacando a necessidade de se votar com consciência cristã. Interessante perceber que pelo contexto eleitoral, com esta argumentação, o apoio a Bolsonaro era explícito sem necessidade de citar o nome do candidato, as pautas moralistas em defesa da família tradicional e a insatisfação com o fato de Pablo Vittar poder se pronunciar a favor de Haddad deixavam claro o aval a campanha de Bolsonaro.

A matéria foi publicada poucos dias após Haddad proferir severas críticas ao apoio de Edir Macedo a Jair Bolsonaro. Nascimento (2019) aponta que no dia dedicado a padroeira do Brasil, na porta da Basílica de Nossa Senhora, em Aparecida/ SP, o petista afirmara que:

a candidatura de Jair Bolsonaro era um casamento do neoliberalismo desalmado - representado pelas ideias do economista Paulo Guedes - com o fundamentalismo charlatão de Macedo. Sabe o que está por trás dessa aliança? Em latim chama auri sacra fames. Fome de dinheiro. (NASCIMENTO, 2019, p. 292).

Naquele momento já havia forte engajamento de evangélicos conservadores em prol da eleição de Bolsonaro. O semanário questionava "por que um bispo não pode pregar pela melhoria das condições do povo ou não possa debater questões que afligem os fiéis?". Afirmava que o medo de quem queria calar as igrejas era de que os cristãos escolhessem candidatos que representassem valores bíblicos como a família, a honra e a honestidade. O "nós" e o "eles" era colocado em posição 
antagônica e vitimista, evidenciando a ideia de que os evangélicos são uma minoria perseguida tanto pelos poderes públicos quanto pela mídia.

Prandi, Santos e Bonato (2019) destacam que as igrejas evangélicas brasileiras constituem verdadeiras máquinas eleitorais, desempenhando papel tão ou mais efetivo que os próprios partidos políticos. Além de se valer do púlpito, não raras vezes acabam oferecendo o serviço de obreiros e voluntários para figurarem como verdadeiros cabos eleitorais dos candidatos; mobilizam redes de contatos de divulgação e execução de serviços necessários as campanhas, fazendo pontes entre candidatos e donos de gráficas, advogados e marqueteiros; bem como podem canalizar recursos para as campanhas eleitorais, ainda que de forma vedada pela legislação eleitoral, motivos estes que justificam a limitação da manifestação política de lideranças religiosas.

As questões apontadas podem ensejar o chamado abuso de poder religioso, instituto amplamente discutido no âmbito jurídico e sociológico. Carvalho Jr. (2019) caracteriza a figura do abuso de poder como toda conduta que envolva a utilização de recursos financeiros ou acesso a bens/serviços que tenha potencialidade para gerar desequilíbrio entre os candidatos. Desta forma, a figura do abuso de poder religioso acontece quando uma liderança religiosa se vale da sua posição privilegiada, da estrutura da igreja, e da fé de seus adeptos para convencê-los a votarem em determinado candidato, por vezes atrelando sua indicação pessoal ou institucional a vontade soberana de Deus.

Embora não haja expressa tipificação legal do abuso de poder religioso, os casos acabam sendo enquadrados pelos tribunais eleitorais em outras modalidades de abuso (econômico, de autoridade ou de uso dos meios de comunicação social), bem como a captação ilícita de sufrágio, cuja sanção pode implicar em multas as igrejas e pastores e na perda do mandato/cassação da chapa do candidato ilicitamente beneficiado.

No editorial intitulado "Acabou a festa: é o fim da velha política" (Ed. 1.384, p. 03), o jornal apontava que a palavra "mudança" definia o resultado das urnas no Primeiro Turno, informando que dentre as 54 cadeiras em disputa no Senado, somente oito foram preenchidas por candidatos que tentaram a reeleição, e que a Câmara dos Deputados Federais teve uma renovação de cerca de 50\% dos seus ocupantes. Complementou que cientistas políticos afirmaram à época que teríamos um perfil mais conservador no Legislativo, com muitos eleitos vindos de instituições como forças de segurança e igrejas evangélicas. Justificavam esse conservadorismo ao eleitor que já está cansado de ver parlamentares que promovem a ruína da família, dos bons costumes, da educação e da ética. Encerrou assegu- 
rando que ainda havia mais a dizer nas urnas no Segundo Turno, e que a minoria que queria "o mais do mesmo" deveria ser abafada em prol das mudanças.

Durante o período eleitoral, em diversas oportunidades a expressão "fim da velha política" foi pronunciada por Bolsonaro como sinônimo da ruptura com as práticas petistas do "toma lá, dá cá”, ou seja, a barganha de cargos de chefia em ministérios e empresas estatais com partidos políticos, a fim de construir uma base de apoio para a aprovação de uma agenda de governo prejudicial ao país e aos brasileiros. Para o presidente, tal prática estimulava a corrupção e desvirtuava a escolha de ministros, privilegiando critérios partidários e preterindo critérios técnicos.

Os governos dificilmente conseguem se estruturar apenas em torno de corpo técnico e "abrir mão" de critérios políticos para garantirem a governabilidade, e não havia uma proposta clara de ruptura com a "velha política", mas como bem enfatiza Bourdieu, as lógicas do campo político se diferem de outros campos, inclusive do científico, porque a força das ideias não se mede pelo valor de verdade, mas pela "força de mobilização que elas encerram, quer dizer, pela força do grupo que as reconhece, nem que seja pelo silêncio ou pela ausência de desmentido, e que ele pode manifestar recolhendo suas vozes ou reunindo-as no espaço" (BouRDIEU, 2007, p. 185).

O jornal era muito crítico à forma de fazer política no Brasil e, sem citar diretamente o PT, Fernando Haddad ou outro político, demonstrava uma grande afinidade pelo candidato do PSL que seria eleito para acabar com as velhas práticas. Além disso, Haddad era associado constantemente no meio evangélico como o candidato defensor do "Kit-gay" e representante da corrupção petista. Durante o Segundo Turno, assim como no primeiro, a Folha Universal foi politicamente atuante, mesmo não citando o nome de candidatos. Temas como o "fim da velha política” e a defesa da moral cristã reforçaram a predileção da IURD pela eleição do candidato Jair Bolsonaro e a desmoralização de Fernando Haddad.

Percebemos que os editoriais do jornal durante o Segundo Turno foram mais explícitos que no primeiro. O fato de serem apenas dois candidatos e a enorme possibilidade de vitória de Bolsonaro favorecia essa tendência. Apesar dos editoriais explícitos, as matérias desse mesmo período não eram tematicamente tão engajadas, as pautas caras à campanha de Bolsonaro começavam a ser substituídas pela importância do voto evangélico e a necessidade do engajamento de grupos religiosos na política. Bolsonaro fora eleito com 55,13\% dos votos válidos, contra 44,87\% obtidos por Haddad. 


\section{CONSIDERAÇÕES FINAIS}

Nas edições do semanário Folha Universal publicadas durante o Primeiro Turno verificamos a persistência em explicar a estrutura política e a importância do voto. Entretanto, temáticas como Fake-News e a moral religiosa marcaram a tônica das publicações naquele período, com especial ênfase ao combate a Ideologia de Gênero e a preservação da família.

O jornal não fez qualquer menção direta ao nome de Jair Bolsonaro ou outro candidato, contudo é possível identificar afinidades entre os posicionamentos tanto do semanário quanto do presidenciável Bolsonaro, principalmente a defesa de pautas como a preservação da instituição familiar nos moldes heteronormativos e a consequente oposição a Ideologia de Gênero.

Durante o Segundo Turno, verificamos a persistência do semanário em informar os fiéis acerca da importância do voto, instrumento capaz de mudar politicamente do país. Temáticas como o ódio nas redes sociais, a moral religiosa e a defesa do direito de manifestação política de pastores e bispos foram abordadas pelo semanário iurdiano.

Naquele momento havia dois candidatos: Bolsonaro tido como o representante da mudança, e Haddad tido por bolsonaristas como representante da "velha política". A vitória de Jair Bolsonaro já era apontada como certa por diversos institutos de pesquisas eleitorais. Pode-se dizer que a Folha Universal foi politicamente mais atuante no Segundo Turno, mesmo não citando o nome dos candidatos. A exortação ao fim da velha política e a defesa da moral cristã reforçaram a predileção da IURD pela eleição de Bolsonaro e associavam Fernando Haddad à continuidade dos escândalos de corrupção dos governos petistas.

Durante todo o "tempo da política" havia afinidades entre as proposições de Jair Bolsonaro e as pautas da instituição evangélica, entretanto isso não era suficiente para estampar seu nome nas edições do jornal. Havia racionalidade do editorial que apenas se colocou explicitamente no apoio ao candidato quando estava evidenciado que este venceria as eleições.

\section{REFERÊNCIAS BIBLIOGRÁFICAS}

Almeida, Ronaldo de. Bolsonaro Presidente: conservadorismo, evangelismo e a crise brasileira. Novos Estudos - CEPRAP, v. 38, n. 01, p. 185-213, abr. 2019. Disponível em: https://www.scielo.br/scielo.php?script=sci_abstract\&pid=So10133002019000100010\&lng =em\&nrm=iso\&tlng=pt. Acessado em: 20 abr. 2020.

Bourdieu, Pierre. Sobre o Estado: cursos no Collège de France. São Paulo: Companhia das Letras, 2014. 
Bourdieu, Pierre. O campo político. Revista Brasileira de Ciência Política, Brasília, n. 5, p. 193-216, jul. 2011. Disponível em: https://www.scielo.br/scielo.php?script=sci_artt ext\&pid=So103-33522011000100008. Acessado em: 22 abr. 2020

Bourdieu, Pierre. $O$ poder simbólico. Tradução Fernando Tomaz - $11^{\mathrm{a}}$ edição. Rio de Janeiro: Editora Bertrand Brasil, 2007.

Bourdieu, Pierre. A Economia das Trocas Simbólicas. Organização de Sérgio Miceli. 6 ed. São Paulo: Editora Perspectiva, 2005.

BRASIL. Divulgação de candidatos apresidência da república em 2018. Site do Tribunal Superior Eleitoral.Disponível em: http://www.tse.jus.br/eleicoes/eleicoes-2018/ votacao-e-resultados/resultadoseleicoes-2018. Acessado em: 06 mai. 2020.

Carvalho JR., Roberto Camilo de. O Abuso de Poder Religioso no processo eleitoral brasileiro. Biblioteca do Tribunal Superior Eleitoral. Brasília: 2019. Disponível em: http://bibliotecadigital.tse.jus.br/xmlui/bitstream/handle/bdtse/5774/2019_ carvalhojunior_abuso_poder_religioso.pdf?sequence=1\&isAllowed=y. Acessado em: 16 jun. 2020.

Conrado, Flávio César. Política e Mídia: a Igreja Universal do Reino de Deus nas eleições. Religião e Sociedade, Rio de Janeiro, v. 21, n. 02, p. 85-111, 2001. Disponível em: https://www.academia.edu/33084312/Pol\%C3\%ADtica_e_M\%C3\%ADdia_A_ Igreja_Universal_do_Reino_de_Deus_nas_Elei\%C3\%A7\%C3\%B5es. Acessado em: 20 mar. 2020.

Cruz, Marcelo Pereira. A Igreja Universal do Reino de Deus no “Jogo do Poder”: a aliança com o Partido dos Trabalhadores nas eleições presidenciais de 2002. Dissertação de Mestrado, São Paulo, PUC-SP, 2009. Disponível em: https://tede2.pucsp.br/handle/ handle/2113. Acessado em: 28 jun. 2020.

FrAZÃo, Felipe. Edir Macedo declara apoio a Jair Bolsonaro. Estadão, 30 de setembro de 2018. Disponível em: https://politica.estadao.com.br/noticias/eleicoes,edir-macedodeclara-apoio-a-bolsonaro,70002526353. Acessado em: 06 mai. 2020.

Freston, Paul. Protestantes e política no Brasil: da Constituinte ao impeachment. Tese de Doutorado, Campinas, IFCH-Unicamp, 1993. Disponível em: http://repositorio. unicamp.br/jspui/handle/REPOSIP/279821. Acessado em: 28 abr. 2020.

Gutierrez, Carlos. "A Igreja Universal e o Partido Republicano Brasileiro: conflitos em torno do secularismo". In: ARAúJo, Melvina.; CunHa, Chistina Vital da (Org). Religião e Conflito. Curitiba: Editora Prismas, 2016, p. 63-75.

IbGE - Instituto Brasileiro De Geografia E Estatística. Resultado dos Dados do Censo 2000 e 201O. Disponível em: https://sidra.ibge.gov.br/Tabela/137. Acessado em 14 mai. 2020. Mariano, Ricardo. Neopentecostais: sociologia do novo pentecostalismo no Brasil. São Paulo: Edições Loyola, 2014. 
Mariano, Ricardo; Gerardi, Dirceu André. "Apoio evangélico a Bolsonaro: antipetismo e sacralização da direita”. In: Guadalupe, José Luis Pérez; Carranza, Brenda. Novo ativismo político no Brasil: os evangélicos do século XXI. Rio de Janeiro: Konrad Adenauer Stiftung, 2020, p. 329-350.

Martins, Cáio César Nogueira. Religião e Política na Igreja Universal: um estudo acerca da mobilização de conteúdo político/eleitorais pelo Jornal Folha Universal no ano de 2018. Trabalho de conclusão do curso de Ciências Sociais - UEMG. Barbacena, 2020.

Mouffe, Chantal. Sobre o Político. 1. ed. Tradução de Fernando Santos. São Paulo: Martins Fontes, 2015 .

Nascimento, Cláudia Cerqueira do. Igreja como Partido: capacidade de coordenação eleitoral da Igreja Universal do Reino de Deus. Tese de Doutorado, São Paulo, FGV, 2017. Disponível em: https://bibliotecadigital.fgv.br/dspace/handle/10438/20151. Acessado em: 25 jun. 2020.

NAscimento, Gilberto. O Reino: a história de Edir Macedo e uma radiografia da Igreja Universal. São Paulo: Companhia das Letras, 2019.

Oro, Ari Pedro. A Política da Igreja Universal e seus reflexos nos campos religioso e político brasileiros. Revista Brasileira de Ciências Sociais, Rio de janeiro, v. 18, n. 53, p. 52-79, out. 2003. Disponível em: https://www.scielo.br/pdf/rbcsoc/v18n53/18078. pdf. Acessado em: 04 mai. 2020.

Palmeira, Moacir. "Eleição Municipal, política e cidadania”. In: Palmeira, Moacir; Barreira, César (orgs.). Política no Brasil: visões de antropólogos. Rio de Janeiro: Relume Dumará: Núcleo de Antropologia da Política /UFRJ, 2006, p. 137-150.

Palmeira, Moacir. "Política, Facções e Voto". In: Palmeira, Moacir; Goldman, Marcio. Antropologia, voto e representação política. Rio de Janeiro: Contra Capa Livraria. 1996, p. 41.57.

Palmeira, Moacir. Voto: racionalidade ou significado. Revista Brasileira de Ciências Sociais. Brasília, n. 20, ano 7, out. 1992. Disponível em: http://www.anpocs.com/ images/stories/RBCS/20/rbcs20_04.pdf. Acessado em 16 jul. 2020.

Prandi, Reginaldo; Santos, Renan Willian dos; Bonato, Massimo. Igrejas Evangélicas como máquinas eleitorais no Brasil. Revista USP, São Paulo, n. 120, p.43-60, janeiro/ fevereiro/março 2019. Disponível em: https://www.revistas.usp.br/revusp/article/ view/155530. Acessado em 16 out. 2020.

Recuero, Raquel Gruzd, Anatoly. Cascata de Fake News Políticas: um estudo de caso no Twitter. Revista Galaxia, São Paulo, n. 41, p. 31-47, mai-ago. 2019. Disponível em http://dx.doi.org/10.1590/1982-25542019239035. Acessado em: 11 jun. 2020.

ReIs, Toni; EgGERT, Edla. Ideologia de Gênero: uma falácia construída sobre os planos de educação brasileiros. Revista Educação e Sociedade, Campinas, v. 38, n. 138, p. 
9-26, jan-mar. 2017. Disponível em: https://www.scielo.br/pdf/es/v38n138/16784626-es-38-138-00009.pdf. Acessado em: 29 jun. 2020.

RochA, Maria da Penha Nunes. As estratégias de comunicação da Igreja Universal do Reino de Deus. Tese de Doutorado, Rio de Janeiro, UFRJ, 2006. Disponível em: http:// livros01.livrosgratis.com.br/cpo21807.pdf. Acessado em: 29 mai. 2020.

Rodrigues, Elisa. Pentecostalismo, Política e Conservadorismo. Curso de extensão oferecido pela UFJF em junho de 2020. Disponível em: https://www.youtube.com/ watch?v=B2ToAEao8eU\&t=295s. Acessado em: 11 jun. 2020.

Recebido: 27/10/2020 | Aprovado: 21/03/2021 